\title{
Effect of Sesame-Supplemented Diet on Prostate and Seminal Vesicle Histology of Adult Rat
}

\author{
Efecto de la Dieta Suplementada con Sésamo en la Histología \\ de la Próstata y Vesícula Seminal de Ratas Adultas
}

Javad Amini Mahabadi"; Hassan Hassani Bafrani* \& Hossein Nikzad

MAHABADI, J. A.; BAFRANI, H. H. \& NIKZAD, H. Effect of sesame-supplemented diet on prostate and seminal vesicle histology of adult rat. Int. J. Morphol., 34(2):604-609, 2016.

SUMMARY: Infertility is a great concern among the people of reproductive age. The use of natural products obtained from traditional herbs is appealing. Studies show that antioxidants are important in improving male infertility. Thirty adult male rats were randomly divided into two regimen and control groups. The regimen group received diet containing $30 \%$ sesame seed, while the control group received standard diet for 12 weeks. Histology of prostate and seminal vesicle were evaluated and serum levels of FSH, LH and testosterone concentrations were assessed as well. The results showed that, the diameter of peripheral epithelium and the volume density of the prostate epithelium increased but the volume density of the prostate stroma was decreased significantly in the regimen group compared to the control group. Central epithelium diameter and the volume density of the prostate lumen did not change significantly between two groups. In seminal vesicle, volume density of fibromascular and lumen decreased significantly in regimen group compared to control group. FSH andTestosterone level did not change while LH concentration increased significantly in the regimen group compared to the control group ( $\mathrm{P}<0.03)$. This study shows that the sesame seed might improve male rat reproductive systems by histopathological changes in prostate and seminal vesicle.

KEY WORDS: Prostate; Seminal vesicle; Sesame seed; Sperm; Hormone.

\section{INTRODUCTION}

Infertility is a great concern among the people of reproductive age. In recent decades, the observed infertility in wildlife and humans has increased (Sainath et al., 2011). There is a wide range of causes for infertility that includes ovulatory disorders, tubal disease, endometriosis, chromosomal abnormalities, sperm factors and unexplained infertility (Homan et al., 2007). Since there is always a chance for some side effects from different available drugs, the use of natural products obtained from traditional herbs with antioxidant property has been frequently applied in infertility treatment (Zanoli et al., 2008).

The prostate is a key gland in the sexual physiology of male mammals. Its location in the reproductive tract influences several vital functions as those related to micturition, seminal emission and ejaculation (Hernandez et al., 2006).

The prostate gland secretes diverse constituents, including proteins, carbohydrates, lipids, ions, etc., into the semen. The rat prostate has been used extensively as a model system to study androgen regulation of growth and function in this gland (Wilson et al., 1993).

The seminal vesicle secretes a yellow viscous fluid containing substances that activate sperm (fructose). This fluid constitutes about $70 \%$ of the human ejaculate (Ukwenya et al., 2008). Although the seminal vesicle may not contain factors that are absolutely responsible for fertilization but their secretion still plays an important role in optimizing conditions for sperm viability, motility and survival as well as sperm transport (Comhaire et al., 2000; Suja et al., 2005).

Sesame belongs to the family Pedaliaceae and genus Sesamum. It is one of the richest food source of lignans, a major type of phytoestrogens known to man since the dawn of civilization (Thompson et al., 1991) and is now been increasingly incorporated into human diets because of its reported health benefits (Shittu et al., 2008). Sesame lignans such as sesamin, episesamin, sesamolin, and sesamol isolated from Sesamum indicum and radiatum seeds among other 
species are implicated as having certain properties such as antitumorigenic (Hirose et al., 1992), estrogenic and or antiestrogenic (Collins et al., 1997) and antioxidant (Jeng \& Hou, 2005). The proximate analysis of sesame seed indicates that it contains about $50-60 \%$ oil, $8 \%$ protein, $5.8 \%$ water, $3.2 \%$ crude fiber, $18 \%$ carbohydrate, $5.7 \%$ ash and it is very rich in minerals such as $\mathrm{Ca}, \mathrm{P}$ and vitamin $\mathrm{E}$ (Obiajunwa et al., 2005).

Ashamu et al. (2010) has worked on efficacy of vitamin $\mathrm{C}(\mathrm{VC})$ and ethanolic extract of Sesamum indicum (EES) in promoting fertility in male Wistar rats and reported that EES or $\mathrm{VC}$ and more importantly EES+VC are capable of significantly increasing body weight gain, seminal vesicle parameters, testosterone level, and body antioxidant activities.

Sakr et al. (2012) studied the effect of selenium (the sesame antioxidant) on carbimazole induced histopathological and histochemical alterations in prostate of albino rats and revealed that selenium treatment could ameliorate the toxicity induced by carbimazole in prostate gland. This effect of selenium may be attributed to its antioxidant effect.

Youssef et al. (2003) reported that administration of vitamin $\mathrm{E}$, ascorbic acid and their combination can cause significant improvements in rabbit sperm characteristics.

The purpose of the study was to examine the effect of diet containing sesame seed on prostate and seminal vesicle histopathology and sex hormone levels in adult Wistar rat.

\section{MATERIAL AND METHOD}

Rats: Thirty healthy adult Wistar rats weighing $200 \mathrm{~g}$ were obtained from animal center of Kashan University of Medical Sciences and were randomly divided into control and regimen groups (each 15 rats). Those in control group were fed a standard pellet diet and animals in regimen group received a mixture of standard diet and sesame seed (70\% and $30 \%$ ) for 12 weeks. Rats were kept in wire cages in the animal house of University with controlled light ( $12 \mathrm{~h}$ light: $12 \mathrm{~h}$ dark) and humidity ( $55 \pm 5 \%)$ at room temperature $(22 \pm 2$ ${ }^{\circ} \mathrm{C}$ ). During the study (12 weeks) rats had free access to water and food.

The food mixture: Sesame seeds available in the market, was powdered with domestic mill and was mixed with the powdered normal rat food (30\% and $70 \%)$. By adding and mixing with some water, the pasty material was turned to tubular shaped with a pastry cone and was dried in trays for 2-3 days in open air.
Qualitative and quantitative studies: The weight of rats was measured with a digital scale and recorded every week.

After anesthesia, an incision on the chest and abdomen was made to take a blood sample from heart for hormonal assay and seminal vesicle and prostate gland were removed for histology as well.

Serum Hormonal Assay: Serum FSH and LH concentration were estimated with the FSH and LH kit from Glory Company made of china using ELISA technique, while serum testosterone estimation was done with the kit monobind using ChemoLuminance method. Histology seminal vesicle and prostate gland samples were fixed in Bouin's solution and processed with an Autotechnicon tissue processor to prepare paraffin blocks. Then $5 \mu \mathrm{m}$ thick sections were cut and stained with $\mathrm{H}$ \& E for a light microscopic examination.

\section{Morphometric parameters}

Prostate: Peripheral and central epithelium diameters $(\mu \mathrm{m})$ were measured in prostate gland. Also the volume density $(\mathrm{Vv})$ of the prostate gland epithelium, lumen and stroma were measured for morphometrical analysis (Hess, 1990). The peripheral and central epithelium of prostate was measured in 5 random selected cross sections in one slide and 6 reading from each section (Oliveira et al., 2001) to calculate a mean value of 30 reading from each slide.

Seminal vesicle: The epithelial and fibromascular height of the seminal vesicle (right and left) were measured as well as volume density of epithelium, lumen and fibermascular in 6 times in each of 5 sections in one slide (mean value of 30 readings) (Justulin et al., 2006).

Statistical analysis: The data were prepared as Mean \pm SEM and statistical analysis were performed using one way ANOVA analysis andstudent's t-test. A p value of $(\mathrm{P}<0.05)$ was considered to be significant.

\section{RESULTS}

Body weight: The body weight of two groups did not change significantly during the study. Moreover, daily observation showed no clinical and behavioral changes in the animals treated with the sesame seed during the study (Table I).

Serum hormone (LH, FSH and T) levels: LH level was increased significantly in regimen group compared to the control group but no significant changes was seen for FSH or testosterone levels between two groups (Table I). 
Table I. Effects of the sesame seed on body weights (g) and hormones concentration of Wistar male rats treated during 12 weeks.

\begin{tabular}{lcc}
\hline Parameters & Control & Regimen \\
\hline Body weights $(\mathrm{g})$ & $195.88 \pm 7.67$ & $194.42 \pm 8.04$ \\
LH $(\mathrm{IU} / \mathrm{L})$ & $2.7 \pm 0.29$ & $3.5 \pm 0.22^{*}$ \\
FSH $(\mathrm{mIU} / \mathrm{L})$ & $3.9 \pm 0.44$ & $3.3 \pm 0.28$ \\
$\mathrm{~T}(\mathrm{nmol} / \mathrm{L})$ & $10.88 \pm 2.9$ & $8.45 \pm 2.9$ \\
\hline
\end{tabular}

Results expressed in mean \pm SEM (Standard Error of Mean) $(n=15)$.

Table II. Effects of the sesame seed on prostatic morphometric evaluation of Wistar male rats treated during 12 weeks.

\begin{tabular}{lcc}
\hline \multicolumn{1}{c}{ Parameters } & Control & Regimen \\
\hline Central epithelium diameter $(\mu \mathrm{m})$ & $9.94 \pm 0.42$ & $11.02 \pm 0.41$ \\
Peripheral epithelium diameter & $16.85 \pm 0.51$ & $23.11 \pm 2.86^{*}$ \\
Vv lumen (\%) & $55.58 \pm 2.16$ & $53.58 \pm 2.54$ \\
Vv epithelium (\%) & $24.85 \pm 1.27$ & $31.34 \pm 1.87^{* *}$ \\
Vv stroma (\%) & $19.56 \pm 1.54^{*}$ & $15.07 \pm 1.44$ \\
\hline
\end{tabular}

Data are reported as mean $\pm \operatorname{SEM}(\mathrm{n}=15)$. Statistically significant differences: * $\mathrm{P}<0.05$ Volume density ( $\mathrm{Vv}$ ) of the prostatic glandular epithelium, glandular lumen and fibromascular stroma in the control and regimen groups.

Table III. Volume density $(\%)$ and diameter $(\mu \mathrm{m})$ of the components of seminal vesicle of Wistar rats treated during 12 weeks.

\begin{tabular}{lcc}
\hline Parameters & Control & Regimen \\
\hline Fibromascular diameter & $125.51 \pm 4.11^{* * *}$ & $85.43 \pm 5.86$ \\
Epithelium diameter $(\mu \mathrm{m})$ & $17.75 \pm 0.84$ & $27.45 \pm 0.29 * * *$ \\
Vv fibromascular layer $(\%)$ & $31.54 \pm 1.04 * *$ & $28.02 \pm 0.96$ \\
Vv epithelium $(\%)$ & $41.69 \pm 1.16$ & $54.16 \pm 0.78^{* * *}$ \\
Vv lumen (\%) & $26.76 \pm 1.15^{* * *}$ & $17.81 \pm 0.82$
\end{tabular}

Data are reported as mean \pm SEM $(n=15)$. Statistically significant differences: $*=P$ $<0.05$ Volume density $(\mathrm{Vv})$ and diameter seminal vesicle in the control and regimen groups.
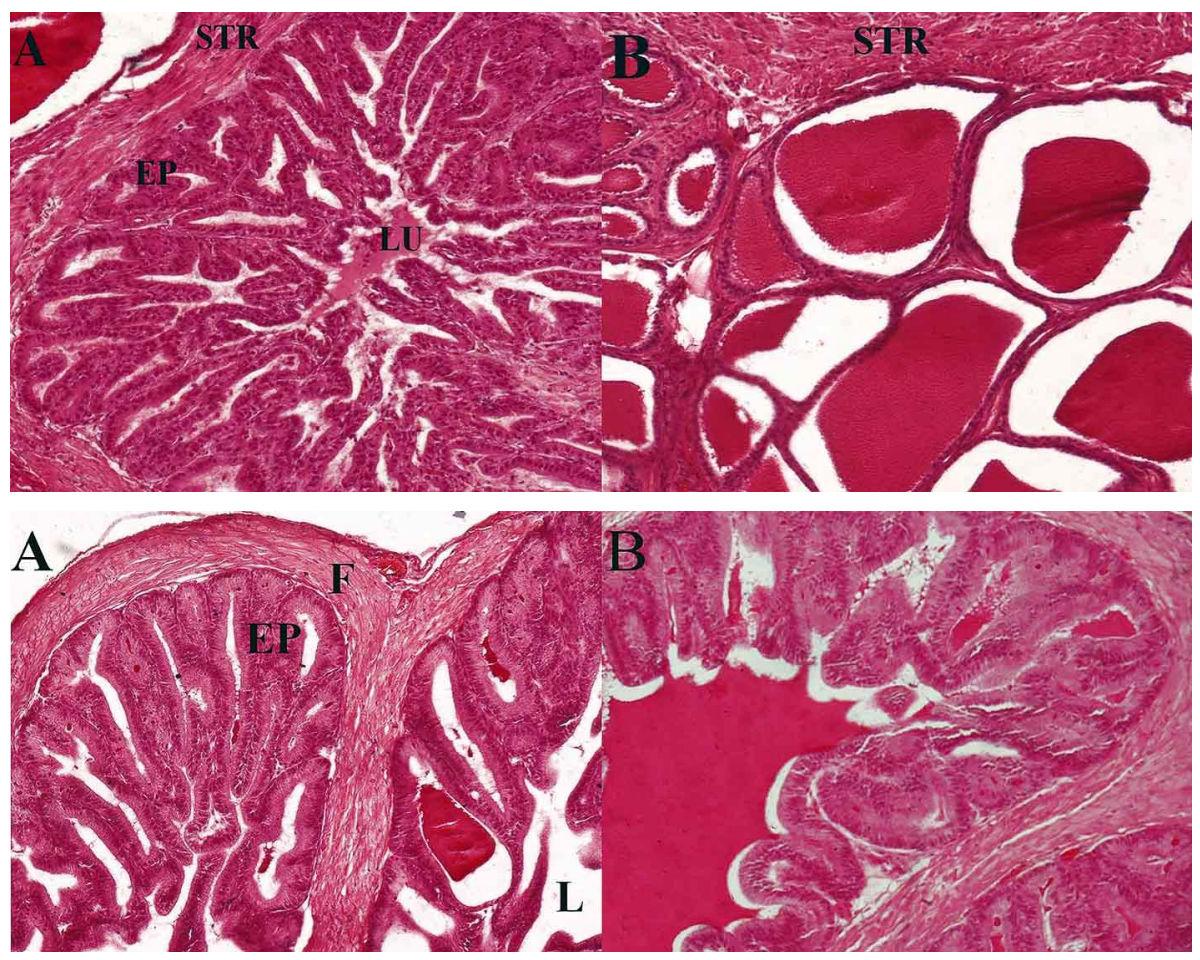

Prostatic morphometric evaluation. According to the results of this study, the diameter of peripheral epithelium in the regimen group showed a significant increase compared to the control group $(\mathrm{P}<0.05)$, but no significant change of central epithelium diameter was found between the two groups (Table II). In the regimen group, the volume density of the prostate epithelium increased but the volume density of the prostate stroma decreased significantly (Table II, Fig. 1).

Microscopic sections of the prostate showed that volume density of peripheral epithelium was clearly increased (Fig. 1) whereas the volume density of stroma has been decreased in regimen group (A) compared to the control group (B).

Seminal vesicle morphometric evaluation. In seminal vesicle of regimen group, volume density of epithelium was increased ( $\mathrm{P}<0.05)$, but volume density of fibromascular and lumen decreased significantly ( $\mathrm{P}$ $<0.05$ ) compared to control group (Table III, Fig. 2).

Microscopic sections of the seminal vesicle showed a similar result. In regimen group (A), volume density and thickness of epithelium was increased but volume density of stroma was decreased in comparison to the control group (B).
Fig. 1. Photomicrograph of prostate in regimen and control groups (H \& E X 100). A) Prostate sections from regimen rats. B) Prostate sections from control rats. $\mathrm{STR}=$ stroma; $\mathrm{EP}=$ epithelium; LU0 lumen.

Fig. 2. Photomicrograph of seminal vesicle in regimen and control groups (H \& E X100). A) Seminal vesicle sections from regimen rats. B) Seminal vesicle sections from control rats.

$\mathrm{F}=$ fibromascular; $\mathrm{EP}=$ epithelium; $L U=$ lumen. 


\section{DISCUSSION}

The purpose of the study was to examine the effects of sesame seed-supplemented diet on prostate and seminal vesicle histology and sex hormones of adult rat.

Our results showed that LH levels significantly increased in regimen group compared to controls but no significant changes in FSH and testosterone levels were seen between two groups.

In male, LH and its receptors (LHR) are necessary for the synthesis of testosterone by testis interstitial endocrine cells (Leydig cells) and to regulate the epididymal epithelial morphology and epididymal steroidogenesis. FSH binds to its receptor (FSH-R) in somatic sustentocytes (Sertoli cells) and stimulates the production and secretion of numerous proteins into the seminiferous tubular lumen (Swider-AlAmawi et al. 2010).

One possible explanation for decreased testosterone in regimen group is that some of the hormone been aromatized to estradiol (E2) by sesame phytoestrogens and/or converted to dihydrotestosterone (DHT) by the aromatize and reductase enzymes (Shittu Lukeman et al., 2008). Hess \& Carnes (2004) has also shown that estrogen is responsible for maintaining the differentiated epithelial morphology through an unknown mechanism. Overall these studies show that, estrogen or its receptor is important for normal functioning of the male reproductive tract in animal species and humans.

Shittu et al., has shown that both FSH and testosterone play a role in the spermatogenic process. For example, FSH is involved in increasing spermatogonial number and the maturation of spermatocytes, including meiosis, while spermatid maturation is essentially testosterone dependent, a step that cannot be completed in spite of high FSH.

According to the results, the diameter of peripheral epithelium and the volume density of the prostate epithelium were increased in regimen group significantly $(P<0.05)$ compared to the control group.

One possible explanation for the increased prostate epithelium is the antioxidants (vitamin $\mathrm{E}$ and/or vitamin $\mathrm{C}$ ) activity of sesame seeds that have been demonstrated to improve reproductive function in laboratory and farm animals (Taylor, 2001). Andreea \& Stela (2010) reported that vitamin $\mathrm{E}$ (one of sesame antioxidants) (Obiajunwa et al.) is considered to be the main component of the antioxidant system of spermatozoa, one of the major protectors of the membranes against ROS and LPO attack (Yousef et al.).
Wilson et al. (2003) reported that although vitamin E deficiency does not alter the growth of the prostatic lobes, nor the onset and extent of lateral lobe specific prostatitis, but it may delay some differentiated functions such as secretion of specific proteins in the ventral lobe.

Hoenjet et al. (2005) showed that selenium may be useful in the prevention of prostate cancer. It's been reported that sesame seed has high amount calcium and phosphor (Obiajunwa et al.).

Raimondi et al. (2010) in their study found that, calcium from dairy products is correlated to lower risk of prostate cancer. Colao et al. (2000) resulted that testosterone and DHT are the main stimulator factors of prostate growth. Longstanding GH and/or IGF-I deficiency induced a decrease in prostate size mostly in patients with concomitant testosterone deficiency.

Our results showed that volume density of the seminal vesicle epithelium was increased but volume density of fibromascular and lumen decreased significantly in regimen group compared to control group.

Mohammad \& Daradka (2009) results showed that the aqueous extracts of Nigella sativa had increased spermatogenesis of male albino rats. Also, they found that with histology diameter increasing in the reproductive organs such as seminal vesicle, sperm count increased. Mukerjee \& Rajan (2006) reported that consequential effect of prolonged stress through the pre-weaning and post-weaning period of laboratory rats, the weight of seminal vesicles and the histological features of the mucosa been severely affected.

Nordberg (1975) in their study found that the toxic effect of cadmium $(\mathrm{Cd})$ on seminal vesicle results in some effects similar to a decreased testosterone level.

However, the results are in disagreement with those of Nordberg study, in which he found that cadmium has toxic effects on multiple organs, including the seminal vesicle. This difference may be due to the fact that he studied effects of long-term cadmium exposure on the seminal vesicles of mice, while were studying the effects of a diet contain sesame seed on histopathology of seminal vesicle in adult Wistar rat.

CONCLUSION. Our results show that sesame seed improves different parameters in prostate and seminal vesicle including enhanced LH and histology. Since some of the 
histological changes caused by sesame are opposed to the changes caused by toxic elements like cadmium. Therefore besides using sesame as supplement diet, it might be used as a detoxification agent where is necessary.
ACKNOWLEDGMENTS. This study was part of the project (number 8943). The authors would like to thank research deputy of Kashan University of Medical Sciences for financial support.

MAHABADI, J. A.; BAFRANI, H. H. \& NIKZAD, H. Efecto de la dieta suplementada con sésamo en la histología de la próstata y vesícula seminal de ratas adultas. Int. J. Morphol., 34(2):604-609, 2016.

RESUMEN: La infertilidad es una gran preocupación para las personas en edad reproductiva y el uso de productos naturales obtenidos a partir de hierbas tradicionales es interesante. Los estudios demuestran que los antioxidantes son importantes en la mejora de la infertilidad masculina. Treinta ratas macho, adultas, se dividieron aleatoriamente en dos grupos, experimental y control. El grupo experimental recibió dieta con un $30 \%$ de semillas de sésamo, mientras que el grupo control recibió dieta estándar durante 12 semanas. Fueron evaluadas la histología de próstata y vesícula seminal, así como los niveles séricos de las concentraciones de FSH, LH y testosterona. Los resultados mostraron que el diámetro del epitelio periférico y la densidad de volumen del epitelio de la próstata aumentaron, pero la densidad de volumen del estroma de próstata se redujo significativamente en el grupo experimental en comparación con el grupo control. El diámetro del epitelio central y la densidad de volumen del lumen de la próstata no presentaron cambios significativos entre los dos grupos. En la vesícula seminal, la densidad de volumen fibromuscular y el lumen se redujeron significativamente en el grupo de régimen en comparación con el grupo control. FSH y el nivel de testosterona no cambiaron, mientras que la concentración de LH aumentó significativamente en el grupo de régimen en comparación con el grupo control $(\mathrm{P}<0,03)$. Este estudio indica que la semilla de sésamo podría mejorar los sistemas reproductivos de ratas macho a partir de cambios histopatológicos en la próstata y las vesículas seminales.

PALABRAS CLAVE: Próstata; Vesícula seminal; Semilla de sésamo; Espermatozoide; Hormona.

\section{REFERENCES}

Andreea, A. \& Stela, Z. Role of antioxidant additives in the protection of the cryopreserved semen against free radicals. Roman. Biotechnol. Lett., 15(3):33-41, 2010.

Ashamu, E.; Salawu, E.; Oyewo, O.; Alhassan, A.; Alamu, O. \& Adegoke, A. Efficacy of vitamin $\mathrm{C}$ and ethanolic extract of Sesamum indicum in promoting fertility in male Wistar rats. J. Hum. Reprod. Sci., 3(1):11-4, 2010.

Colao, A.; Spiezia, S.; Di Somma, C.; Marzullo, P.; Cerbone, G.; Pivonello, R.; Faggiano, A. \& Lombardi, G. Effect of GH and/or testosterone deficiency on the prostate: an ultrasonographic and endocrine study in GH-deficient adult patients. Eur. J. Endocrinol., 143(1):61-9, 2000.

Collins, B. M.; McLachlan, J. A. \& Arnold, S. F. The estrogenic and antiestrogenic activities of phytochemicals with the human estrogen receptor expressed in yeast. Steroids, 62(4):365-72, 1997.

Comhaire, F. H.; Christophe, A. B.; Zalata, A. A.; Dhooge, W. S.; Mahmoud, A. M. \& Depuydt, C. E. The effects of combined conventional treatment, oral antioxidants and essential fatty acids on sperm biology in subfertile men. Prostaglandins Leukot. Essent. Fatty Acids, 63(3):159-65, 2000.

Hernandez, M. E.; Soto-Cid, A.; Rojas, F.; Pascual, L. I.; ArandaAbreu, G. E.; Toledo, R.; Garcia, L. I.; Quintanar-Stephano, A. \& Manzo, J. Prostate response to prolactin in sexually active male rats. Reprod. Biol. Endocrinol., 4:28, 2006.
Hess, R. A. \& Carnes, K. The role of estrogen in testis and the male reproductive tract: a review and species comparison. Anim. Reprod., 1(1):5-30, 2004.

Hess, R. A. Quantitative and qualitative characteristics of the stages and transitions in the cycle of the rat seminiferous epithelium: light microscopic observations of perfusion-fixed and plasticembedded testes. Biol. Reprod., 43(3):525-42, 1990.

Hirose, N.; Doi, F.; Ueki, T.; Akazawa, K.; Chijiiwa, K.; Sugano, M.; Akimoto, K.; Shimizu, S. \& Yamada, H. Suppressive effect of sesamin against 7,12-dimethylbenz[a]-anthracene induced rat mammary carcinogenesis. Anticancer Res., 12(4):1259-65, 1992.

Hoenjet, K. M.; Dagnelie, P. C.; Delaere, K. P.; Wijckmans, N. E.; Zambon, J. V. \& Oosterhof, G. O. Effect of a nutritional supplement containing vitamin E, selenium, vitamin $\mathrm{c}$ and coenzyme Q10 on serum PSA in patients with hormonally untreated carcinoma of the prostate: a randomised placebocontrolled study. Eur. Urol., 47(4):433-9; discussion 43940, 2005.

Homan, G. F.; Davies, M. \& Norman, R. The impact of lifestyle factors on reproductive performance in the general population and those undergoing infertility treatment: a review. Hum. Reprod. Update, 13(3):209-23, 2007.

Jeng, K. C. G. \& Hou, R. C. W. Sesamin and Sesamolin: Natures therapeutic lignans. Curr. Enzym. Inhib., 1(1):11-20, 2005. 
Justulin, L. A.; Ureshino, R. P.; Zanoni, M. \& Felisbino, S. L. Differential proliferative response of the ventral prostate and seminal vesicle to testosterone replacement. Cell Biol. Int., 30(4):354-64, 2006.

Mohammad, M. M. J. \& Daradka, H. Effects of black seeds (Nigella Sativa) on spermatogenesis and fertility of male albino rats. Res. J. Med. Med Sci., 4(2):386-90, 2009.

Mukerjee, B. \& Rajan, T. Morphometric study of seminal vesicles of rat in normal health and stress conditions. J. Anat. Soc. India, 55(1):31-6, 2006.

Nordberg, G. F. Effects on long-term cadmium exposure on the seminal vesicles of mice. J. Reprod. Fertil., 45(1):165-7, 1975.

Obiajunwa, E. I.; Adebiyi, F. M. \& Omode, P. E. Determination of essential minerals and trace elements in Nigerian sesame seeds, using TXRF technique. Pak. J. Nutr. 4(6):393-5, 2005.

Oliveira, C. A.; Carnes, K.; França, L. R. \& Hess, R. A. Infertility and testicular atrophy in the antiestrogen-treated adult male rat. Biol. Reprod., 65(3):913-20, 2001.

Raimondi, S.; Mabrouk, J. B.; Shatenstein, B.; Maisonneuve, P. \& Ghadirian, P. Diet and prostate cancer risk with specific focus on dairy products and dietary calcium: a case-control study. Prostate, 70(10):1054-65, 2010.

Sainath, S. B.; Meena, R.; Supriya, Ch.; Reddy, K. P. \& Reddy, P. S. Protective role of Centella asiatica on lead-induced oxidative stress and suppressed reproductive health in male rats. Environ. Toxicol. Pharmacol., 32(2):146-54, 2011.

Sakr, S. A.; Mahran, H. A. \& Nofal, A. E. Effect of selenium on carbimazole-induced testicular damage and oxidative stress in albino rats. J. Trace Elem. Med. Biol., 25(1):59-66, 2012.

Shittu Lukeman, A. J.; Shittu Remilekun, K.; Adesite Samson, O.; Ajala, M. O.; Bankole Munir, A.; Benebo, A. S.; Tayo, A. O.; Ogundipe Olufemi, A. \& Ashiru Oladapo, A. Sesame radiatum Phytoestrogens Stimulate Spermatogenic Activity and Improve Sperm Quality in Adult Male Sprague Dawley Rat Testis. Int. J. Morphol., 26(3):643-52, 2008.

Shittu, L.; Shittu, R.; Olufemi, O.; Tayo, A. \& Osunubi, A. Hypoglycaemia and improved testicular parameters in Sesamum radiatum treated normo-glycaemic adult male Sprague Dawley rats. Afr. J. Biotechnol., 8(12):2878-86, 2009.

Suja, K. P.; Jayalekshmy, A. \& Arumughan, C. In vitro studies on antioxidant activity of lignans isolated from sesame cake extract. J. Sci. Food Agric., 85(10):1779-83, 2005.

Swider-Al-Amawi, M.; Kolasa, A.; Sikorski, A.; Marchlewicz, M.; Baranowska-Bosiacka, I. \& Wiszniewska, B. The immunoexpression of FSH-R in the ductuli efferentes and the epididymis of men and rat: effect of FSH on the morphology and steroidogenic activity of rat epididymal epithelial cells in vitro. J. Biomed. Biotechnol., 2010:506762, 2010.

Taylor, C. T. Antioxidants and reactive oxygen species in human fertility. Environ. Toxicol. Pharmacol., 10(4):189-98, 2001.

Thompson, L. U.; Robb, P.; Serraino, M. \& Cheung, F. Mammalian lignan production from various foods. Nutr. Cancer, 16(1):43$52,1991$.

Ukwenya, V.; Oluyemi, K.; Ashamu, E.; Saalu, C.; Oyewo, O. \& Makanjuola, V. Profertility effects of alcoholic extract of Sesame in male Sprague-Dawley rats. Internet J. Nutr. Wellness, 5(2), 2008.

Wilson, M. J.; Garcia, B.; Woodson, M. \& Sinha, A. A. Gelatinolytic and caseinolytic proteinase activities in the secretions of the ventral, lateral, and dorsal lobes of the rat prostate. Biol. Reprod., 48(5):1174-84, 1993.

Wilson, M. J.; Kaye, D.; Smith, W. E.; Quach, H. T.; Sinha, A. A. \& Vatassery, G. T. Effect of vitamin E deficiency on the growth and secretory function of the rat prostatic complex. Exp. Mol. Pathol., 74(3):267-75, 2003.

Yousef, M. I.; Abdallah, G. A. \& Kamel, K. I. Effect of ascorbic acid and Vitamin E supplementation on semen quality and biochemical parameters of male rabbits. Anim. Reprod. Sci., 76(1-2):99-111, 2003.

Zanoli, P.; Benelli, A.; Zavatti, M.; Rivasi, M.; Baraldi, C. \& Baraldi, M. Improved sexual behavior in male rats treated with a Chinese herbal extract: hormonal and neuronal implications. Asian J. Androl., 10(6):937-45, 2008.

\section{Correspondence to: \\ Hassan Hassani Bafrani \\ Gametogenesis Research Center \\ Kashan University of Medical Science \\ Kashan \\ IRAN}

Email: hhassanib@gmail.com

Received: 08-12-2015

Accepted: 30-03-2016 